プラズマジェット CVD ダイヤモンド膜形成におよばす非ダイヤモンド質の影響

松本 史朗的1，加藤周一郎放1，富井 洋一队2

和1 日本アルミ，テ532 大阪市淀川区三津屋北2-15-28

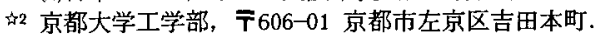

\title{
Effect of Non-diamond Material on the Diamond Film Formation by Plasma Jet GVD
}

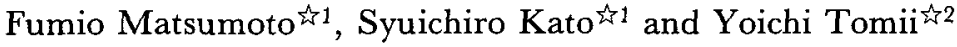 \\ t1 Technical Development Depatment, Nippon Aluminium Co., Ltd., 2-15-28 Mituyakita Yodogawa-ku, \\ Osaka 532. \\ \{2 Department of Metal Science and Technology, Kyoto University, Yoshida Sakyo-ku, Kyoto 606.
}

Received September 9, 1992

A chemical vapour deposited diamond film was grown on a SiC substrate by the plasma arcjet method. The deposited film was circular and appeared to be radially zoned by visual examination. Microfocus Raman spectroscopy was used to examine the radial compositional variation of the film and SEY was used to examine the surface morphologies corresponding to the various zones. Raman spectra showed that the composition varied from graphite to diamond while being hydrogenated carbon. SEI observation showed that amorphous carbon was hydrogenated into hydric carbon, and that included a microcrystalline diamond and prevented the growth of the diamond. As a result, a microcrystalline diamond film zone was produced between graphite zone and polycrystalline diamond zone. The structure and indentation hardness of the microcrystalline diamond film were investigated by TEY observation and micro-Vickers, and also the effect of the microcrystalline diamond film on the overlaped diamond film was investigated by SEY, XRD, Raman spectroscopy. The results were as follows.

(1) The hydric carbon in microcrystalline diamond film looked the matrix material that surrounded the single crystalline diamond of $10-20 \mathrm{~nm}$ size by TEL bright-fild image and TED pattern.

(2) The micro-Vickers hardness of the microcrystalline diamond film was $82 \mathrm{GPa}$ with a load of $9.8 \mathrm{~N}$ at room temperature. The indentation was characteristic of amorphous structure.

(3) The overlaped diamond film on the microcrystalline diamond film layer exhibited flat surface and good crystallinity.

\section{1 緒 言}

天然のダイヤモンドには単結晶型と細かな結晶間を不 純物（特にアパタイト等）で連結している多結晶型があ り，工業用としても用途に応じて使い分けられてきた。 一方，人工的には高圧合成法が主流となり，工業用ダイ
ヤモンド分野で確固たる地位を築いているが、これら 高生合成ダイヤモンドにもサブミクロン以下の均一粒 子は得られにくい，膜状にするにはバインダーが不可 久等の問題点がある。そこで気相合成法にて，原料か スの過飽和度 ${ }^{1}$ ，基板の制御 ${ }^{2}$ 等により得られる粒状 
あるいは膜状タイヤモンドについて検討を行ってきた。 今回, さらに天然ダイヤモンドでは不純物に相当する気 相合成時の非タイヤモンド質の塞態およびタイヤモンド 質との関わりを調べたので報告する。

\section{2 実駿方法}

Fig. 1 に実験装置の模式四を示す。プラズマアークシ エットにCH ${ }_{4}$ 濃度58の原料ガスを投入し, 放射状の温度 分布とそれに対俯するCH 3 /Hラジカルの組成分布をもつ プラズマ照射により約め10mm の目視にても確珰できる同 心円状の領域分布をもつ膜を $\mathrm{SiC}$ 基板上に形成した。基 板の温度分布は基板裏面より $2 \mathrm{~mm}$ 離れた基板ホルダーに 固定されたR-熱電対により，プラズマの温度分布はビデ オの画像をSONY VIDE0-DIGITIZER HBI-V1 でデジタイズ して得られた図形パターンによって測定した。つぎに試 料を動かすことによりセンターを $2.5 \mathrm{~mm}$ ずらし，重ね合 わせた 2 㕌目成膜に及ぼす第 1 層中の非ダイヤモンド質 の影䇺を調べた。実験条件をTable 1 に示す。膜の分析 には微小ラマン分光, XRD, SEM, TEM, マイクロビッカース 硬度测定等を用いた。

\section{3 実殓結果および考察}

\section{1 プラズマ雾囲気の観察}

基板上に照射されたプラズマの温度分布をビデオ像の 256 色表示でデジタイジングして得られた四形パターン と目視にて確認できた膜の模式困をFig. 2 に示す。これ から形成された膜の半径とプラズマアークジェットの半 径 $(\mathrm{r}=5 \mathrm{~mm})$ およびそれらの中心がほぼ一致しているこよ が分かる。プラズマの分割された各温度領域では，C， B 系の熱平衡が成立しているものと考えられ，そこに存在 している各励起種および分子の詳細については前報》で

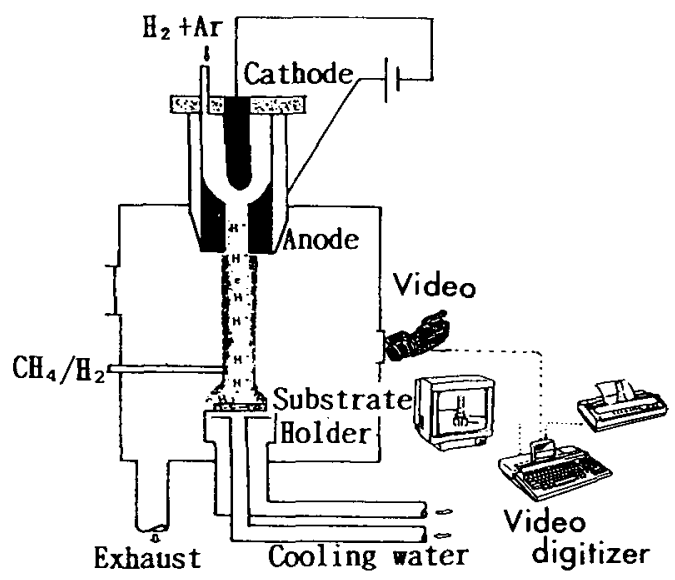

Fig. I Schematic illustration of plasma-jet CVD process.
述べたのでここでは省略する。熱電対による基板温度 測定から膜の中心が最も高温 (1123K)であり，周辺と は約150Kの温度差が認められた。このようなブラズマ 㞣囲気と基板温度の変化により析出膜に同心円状の領 域分布が生じたと考えられる。

Table 1 Experimental condition.

\begin{tabular}{|l|l|}
\hline Substrate & $\mathrm{SiC}$ \\
\hline Plasma gas & $\mathrm{H}_{2}+\mathrm{Ar} \quad 40(\ell / \mathrm{min})$ \\
\hline Reactant gas & $\mathrm{CH}_{4} / \mathrm{H}_{2} \quad 5 \% \quad 8(\ell / \mathrm{min})$ \\
\hline Substrate Temp. & $973 \sim 1123 \quad(\mathrm{~K})$ \\
\hline Total gas press. & $16 \sim 19 \quad(\mathrm{kPa})$ \\
\hline ArcAmp. , Volt & $40 \sim 60(\mathrm{~A}), 60 \sim 80(\mathrm{~V})$ \\
\hline
\end{tabular}

$\mathrm{H}^{*}$ (Atomic hydrogen)

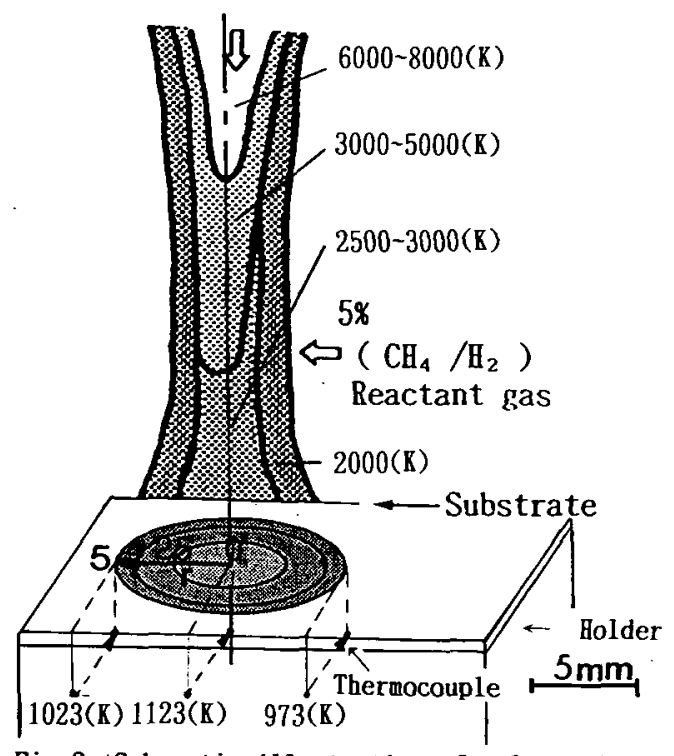

Fig. 2 Schematic illustration of plasma-jet and the deposited film.

\section{2 微小ラマン分光分析}

Fig. 3 に第 1 層目形成膜の半径方向の微小ラマンス ペクトル変化を示す。 $\mathrm{r}=5 \mathrm{~mm}$ の領域(1) $1360 \mathrm{~cm}{ }^{-1}$ の不 規則性グラファイト, $1600 \mathrm{~cm}^{-1}$ のグラファイト， 1520 $\mathrm{cm}^{-1}$ '付近に帰属するポリアセチレン“) と思われるピー クが見られた。 $\mathrm{r}=4$-5m アモルファスカーボンと思われるブロードなビークが

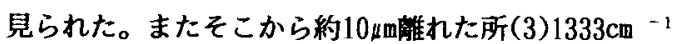
にシャープなダイヤモンドのビークとなだらかなアモ ルファスカーボンと思われるピークをもつものが見ら れた。 $\mathrm{r}=3.5$-4mm の領域(4) 水素化カーボンのなだら かなピーク， r=2.5-3.5m の領域(5) 水素化カーボン とそれに隠蔽されたブロードなダイヤモンドのピーク が見られた。 $\mathrm{r}=0$-2.5mm の領域(6) シャープなダイヤ モンドのみのピークが見られた。 


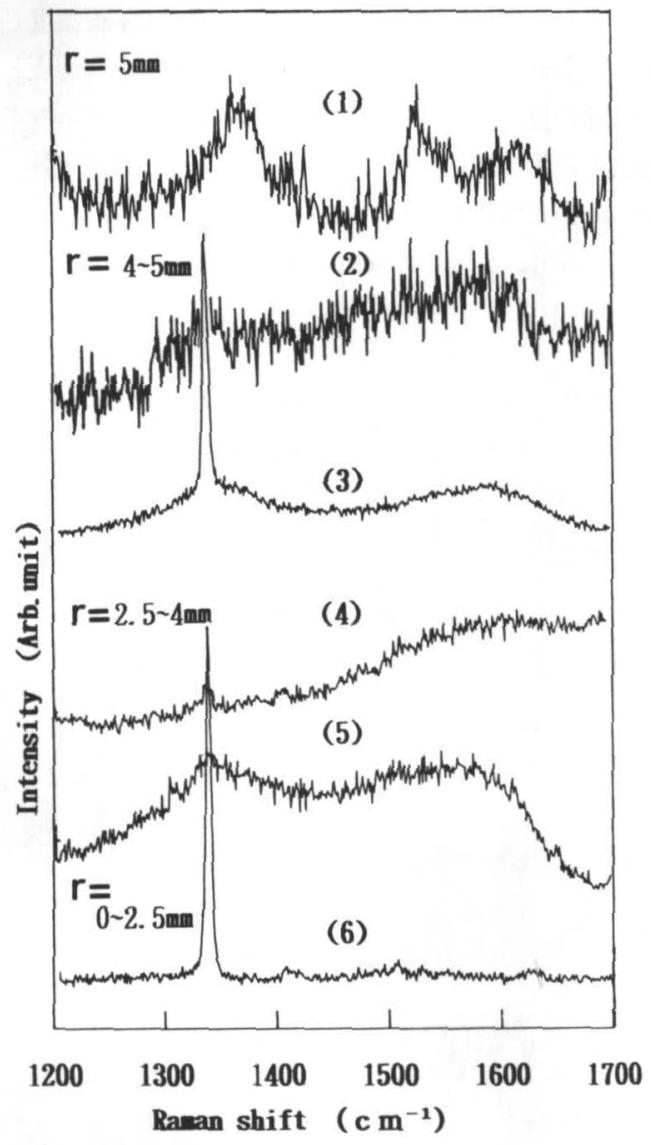

Fig. 3 Raman spectra of the radial compositional variation on the diamond film.

\section{3 析出物のSEM 観察}

Fig. 3 の(1) (6) のラマンスペクトルに対応した析出 物のSEM 写真をFig. 4 に示す。(1) はグラファイトの膜 状の堆積物と思われる。（2）はSiC 上に堆積したアモル ファスカーボンがひげ状に成長した状態である。これは 原子状水素がアモルファスカーボンと反応し水素化カー ボンを形成している過程 ${ }^{5)}$ と考えられる。(3) は(2) か ら約 $10 \mu \mathrm{m}$ 離れた個所で単結晶タイヤモンド粒がアモルフ アスカーボンの上に析出した状態である。（4）は水素化 カーポン粒が幾層にも堆積している様子であり，（5）は それらが膜状化したものと考えられる。後述この領域の TEV 観察から内部に結晶性の良い微結晶ダイヤモンド粒 が多数含まれていることが喼められた。このように水素 化カーボンが粒状化しやすく，しかもダイヤモンドを取 り込みやすい特性はダイヤモンドの成長を阻止し, 微結 晶ダイヤモンド膜を形成するための要因と考えられる。 （6）は結晶性の高い, 表面(100) 面でおおわれたダイヤ
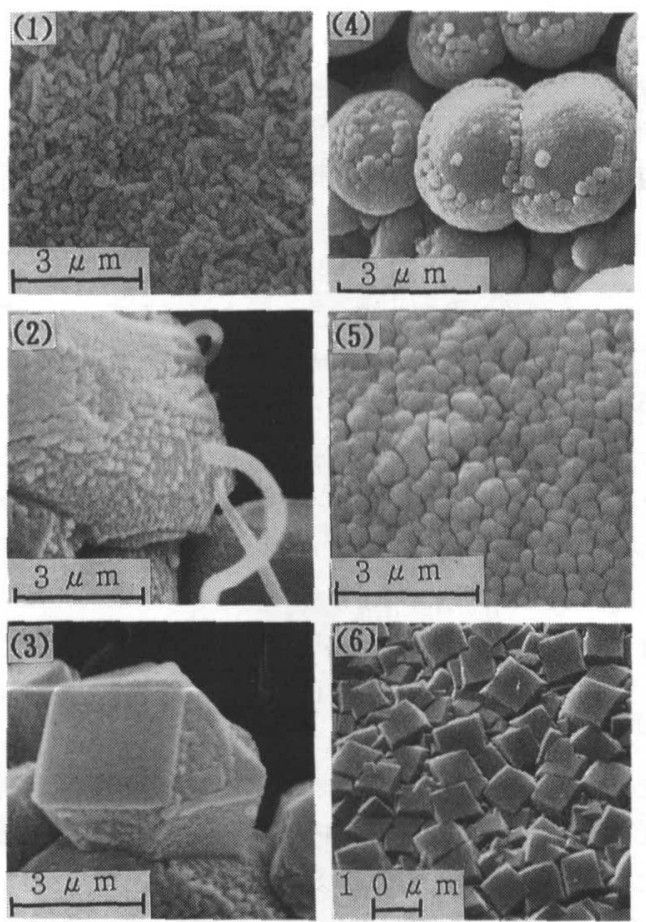

Fig. 4 SEY photographs showing the surface morphology of each zone corresponding to Raman spectra in Fig. 3.
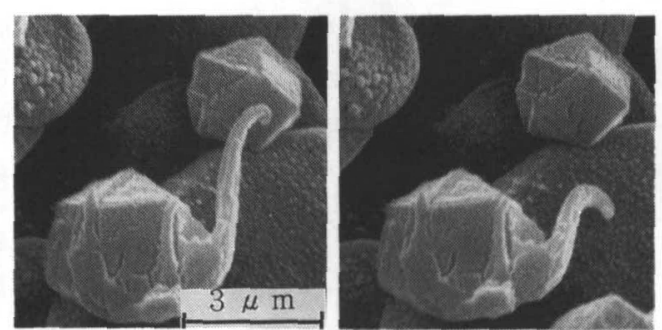

(a) scanning time $=5$ (min)
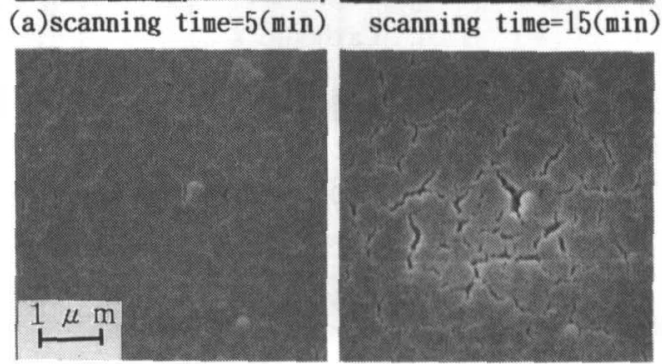

(b) scanning time $=5(\min ) \quad$ scanning time $=15$ (min)

Fig. 5 SEI photographs showing changes of hydric carbon by the heat-damage(scanning time) of SEII. (a) whisker-1ike hydric carbon, (b)film-like hydric carbon. 
モンドのみの膜である。ここで水素化カーボンの特性を 示すものとしてSEV 観察時の高加速電子プローブ(25kV) の照射による熱的感受性をFig. 5 に示す。(a) ではひげ 状に伸びた水素化カーボンが照射時間に依存して縮退し ていくのが分かる。（b）は微結晶ダイヤモンド膜を鏡面 研磨したもので，中に含まれる水素化カーボンがやはり 熱的な影響で分解されていくものと考えられる。

\section{4 微結晶タイヤモンド膜}

Fig. 6 に第 1 層目膜の微結晶タイヤモンド領域のTEI 像およびTED パターンを示す。TEM の明視野像からは矢 旫で示すような格子綗間隔 $0.21 \mathrm{~nm}$, 結晶子サイズ 10 20nm のダイヤモンド粒が散在し，それを取り囲むよう にリボン状の非晶質らしきものが見られた。制限視 野TED パターンからは微結晶化を示す回折リングと単結 晶性を示す回折斑点が見られた。つぎに微結晶ダイヤモ ンド膜を鏡面研磨し、マイクロビッカース硬度測定を行 った結果, 荷重9.8Nで82GPa の値が得られた。これは天

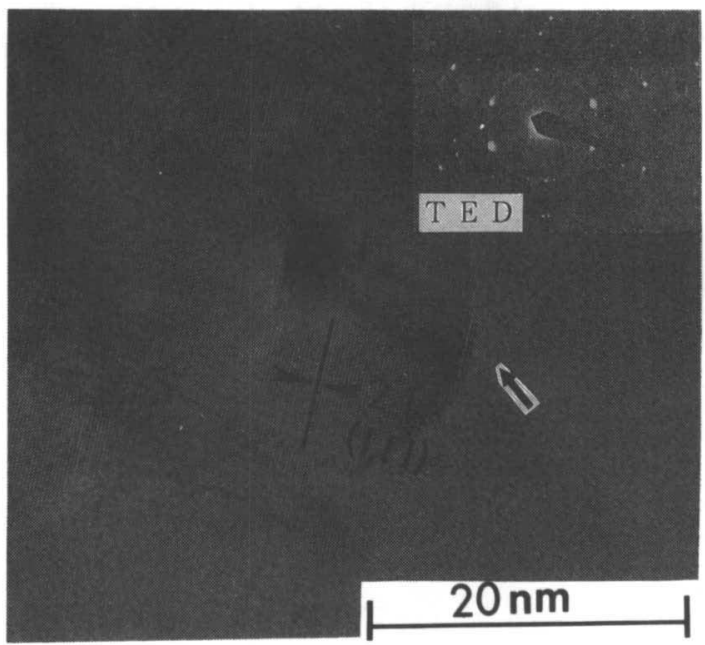

Fig. 6 Transmision electron micrograph and diffraction pattern of microcrystalline diamond film zone.

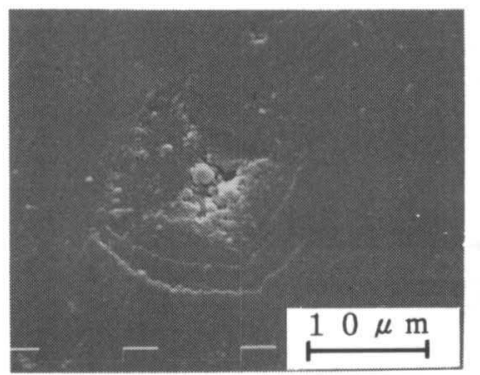

Fig. 7 SEI photograph of the Vickers indentation in microcrystalline diamond film zone.
然ダイヤモンドと同等の值であった。また，測定後の マイクロビッカース硬度計の圧痕周辺部にFig. 7 に示 すようなvein状パターンが見られることから微結晶粒 ダイヤモンドをとりかこむものは非晶質である ${ }^{61}$ と判 断される。

\section{5 非ダイヤモンド質の第 2 層目膜への影響}

プラズマアークジェットの中心を $2.5 \mathrm{~mm}$ ずらし，第 2 層目膜を重ね合わせることにより, 第 1 層目膜

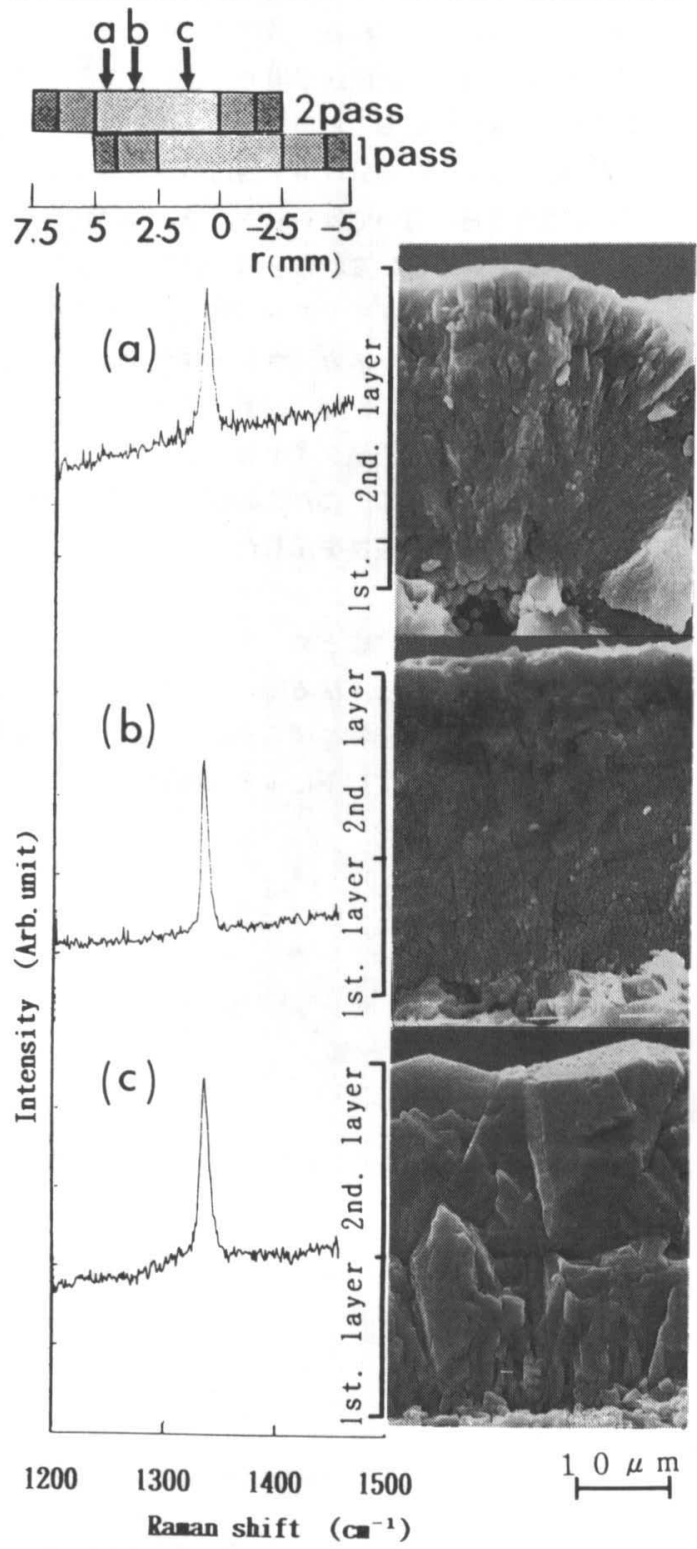

Fig. 8 Cross sectional morphorogy and Raman spectra of the second pass films(a)on the graphite and amorphous carbon layer, (b)on the microcryställine diamond layer, (c)on the polycrystalline diamond layer. 
(a)グラファイト，アモルファスカーボン領域 $(\mathrm{r}=4$ -5m ），(b) 微結晶ダイヤモンド領域( $r=2.5 \sim \mathrm{mm})$ およ び(c) 多結晶ダイヤモンド領域( $\mathrm{r}=0 \sim 2.5 \mathrm{~mm})$ の第 2 層目 膜に及ぼす影㫪を調べた。Fig. 8 に钼察個所およびその 個所の断面モルフォロジーと表面のラマンスペクトルを 示す。グラファイト，アモルファスカーボン領域を下地 とした部分の断面モルフォロジーは膜との界面に間隙が みられ，膜質も不均一であった。これは界面に介在した 非ダイヤモンド質か滵着性を阻害し，その後の結晶成長 に影䈉したためと考えられる。微結晶ダイヤモンド領域 を下地とした部分は膜表面が平坦で，しかも空隙のない 絰密な膜質を示していることが分かる。多結晶ダイヤモ ンド領域を下地とした部分は第 1 層目の多数の柱状的結 晶が第 2 層目膜質においてはおおきくひとつに結合した ように見られる。つぎにこれら 2 層目膜のラマンスペク トルからは $1333 \mathrm{~cm}^{-1}$ のタイヤモンドピークの半值幅がグ ラファイト、アモルファスカーボン下地が $10 \mathrm{~cm}^{-1}$, 微結 晶タイヤモンド下地が $7.5 \mathrm{~cm}^{-1}$, 多結晶ダイヤモンド下

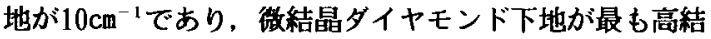
晶性であることが分かる。またこの膜表面のXXR 分析か ら(220) 面の優先配向成辰を示した。

$$
4 \text { まとめ }
$$

プラズマアークジェット法で得られるダイヤモンド・ 非タイイセンド膜の析出物を明らかにし，それらの生成 機構および特性について以下に示す基鿒的知見を得た。
（1）析出膜は円形で放射状にグラファイト，アモルフ アスカーボン，ダイヤモンドまでの炭素の構造変化と 種々の炭化水素化合物が見られた。

（2）アモルファスカーボンは原子状水素と反応して水 素化力ーボンを形成すると考えられる。水素化力ーボ ンはダイヤモンドの結晶成長を停止させ，微結晶から なるダイヤモンド膜を形成するもの之考えられる。

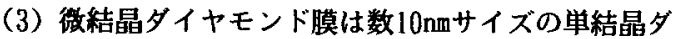
イヤモンドとそれを取り囲む非晶質の水素化カーボン から構成されていると考えられる。

（4）微結晶ダイヤモンド膜を下地層としてその上に形 成されだダイヤモンド膜は高結晶性で，しかも表面が 平坦であった。

\section{文 献}

1)松本史朗，加藤周一郎，冨井洋一：粉体および粉末 治金協会講演概要集平成三年度秋季大会(1991)166.

2)加藤周一郎，松本史朗，冨井洋一：粉体および粉末 治金協会講演概要集平成二年度春季大会 (1990)58.

3)松本史朗，加藤周一郎，富井洋一：粉体および粉末 冶金, 39(1992)910。

4)佐藤進, 渡辺博, 高楿勝緒, 岩木正哉 : 粉体および 粉末冶金, 38(1991)418.

5)早大大学院理工学研究巢赧第38号(1991)134.

6)山内勇，大中逸雄，小柴恵一：日本金属学会誌，56 (1992)658. 